\title{
Assessment of the Availability of Rural Infrastructure, Agricultural Credit and Cooking Fuel among Project and Non- Project Women Farmers in Benue State, Nigeria
}

\author{
Atagher, Monica Mwuese ${ }^{1}$, Atagher, Deborah Maanenge ${ }^{2}$ \\ 1. Department of Agricultural Business Management, Akperan Orshi College of Agriculture Yandev, P.M.B 181, \\ Gboko Benue State, Nigeria. \\ ${ }^{2}$ Department of Agricultural Engineering Technology, Akperan Orshi College of Agriculture Yandev, P.M.B \\ 181, Gboko Benue State, Nigeria.
}

\begin{abstract}
This study assessed the availability of rural roads, water supply, agricultural credit, and cooking fuel among project and non-project women farmers in Benue State, Nigeria. Data collected through structured questionnaire administered to $87 \mathrm{ADP}$ and 87 non-ADP women farmers randomly selected across Benue agricultural development zones, was analysed using descriptive statistics such as means, percentages, bar and pie charts among others. Results showed that over $72-90 \%$ of rural roads in the study area are in poor condition and impassable for certain periods of the year, thereby constraining agricultural activities. Results also showed that only 6-16.1\% of all women farmers studied had access to clean water from public water supply. The rest could not access clean domestic water with possible consequences of ill health, reduced productivity, income and welfare. Results further showed that informal sources such as relatives and friends, money lenders and personal savings of respondents provided the bulk of the funds (95.9\%) for farm operations, while formal sources like commercial banks and the Bank of Agriculture provided the negligible balance (4.1\%). Furthermore, 86-94\% of all study women farmers could only access fuel wood for cooking, and their search for this fuel wood could have undesirable effects on agricultural productivity, sustainable agriculture, and poverty reduction. Policies for provision of more and better rural roads, water supplies, agricultural credit targeted at the women farmers and environmentally friendly sources of cooking fuel such as ethanol gel fuel would improve productivity and reduce poverty in the study area and the nation.
\end{abstract}

Key words: rural infrastructure, agricultural credit, cooking fuel, women farmers, productivity

\section{Introduction}

The importance of infrastructural facilities for agricultural growth and development is well established. Public infrastructure such as good roads, rural water supply, rural electricity, transportation, reliable communication, irrigation services, agricultural research, education and health do not only affect total factor productivity, but also contribute directly to substantial reduction in rural poverty (World Bank, 1994; Nwosu, 2005; Inoni, 2008). According to Jacoby (2000) a good road network and marketing facilities accelerate efficient delivery of farm inputs, produce evacuation, reduce transport costs (up to $50 \%$ in sub-Saharan Africa), and enhance spatial agricultural production and distribution; and enable rural farmers sell their produce at good prices leading to high incomes and high standard of living. Ahmed and Hossain (1990) found that in villages with better access roads, fertilizer costs were $14 \%$ lower, wages were $12 \%$ higher and crop output was $32 \%$ higher in Bangladesh. In India, Fan et al (2000) established that public investment in rural roads and marketing infrastructure had a significant impact on agricultural output and farm income. According to Inoni (2008), investment in rural infrastructure lowered transportation costs, increased farmers' access to markets, and led to substantial expansion in agricultural output. Better roads for instance reduced transaction costs of credit services resulting to increase lending to farmers, higher demands for agricultural inputs, and higher crop yields.

Consequently, efficient economic infrastructure is central to raising productivity and increasing growth in Nigeria. However, evidence show that a weak infrastructural base has been one of the major factors militating against the attainment of the Nigeria's growth and development objectives, namely achievement of stability, material prosperity, peace and social progress since independence in 1960 (UNDP, 2008). The establishment of the agricultural development projects (ADPs) in Nigeria was therefore, seen in part as the country's effort to overcome infrastructural and other deficiencies in the economy. According to the National Agricultural Extension and Research Liaison Services (NAERLS, 1997), the ADP strategy is based on the premise that a combination of factors comprising the right technology, effective extension, access to agricultural inputs, adequate market, and infrastructural facilities are essential to raise agricultural land productivity and improve the living standards of the rural dwellers. 
Apart from physical infrastructure, agricultural credit and availability of cooking fuel are other important factors affecting productivity especially in the study area. Studies indicate that many farmers are poor and trapped in a vicious cycle of poverty because they cultivate small areas of land from which they produce little output, and hence sell only a very small amount, which cannot help in expanding their farms, and acquiring new technologies so the cycle continues. To break out of the vicious cycle of poverty, credit is essential since it determines access to all the resources the farmers depend on (Adegeye and Dittoh, 1985). Agricultural credit is required not just for agricultural production alone, but also for consumption. According to Awotide et al (2008), credit is necessary to make farmers more productive in their labour input and to help them during the lean periods before and after planting season, during which farmers hardly have enough to eat which affects their productivity. Therefore, provision of credit is important in productivity improvement.

Availability of fuel for cooking is an issue that engages the time and energies of women farmers, whose significant contribution to the Nigerian agriculture is well documented (Arene and Omoregie, 1991; Ijere, 1991; Ogbimi and Williams, 2001). Studies show that wood fuel is the predominant form of cooking fuel even in the urban areas of Nigeria as even kerosene has become a luxury item only a few can afford its use now for cooking (Onyekuru and Eboh, 2008). This excessive reliance on fuel wood for cooking is dangerous, and is among the factors responsible for natural resource degradation, which has reduced agricultural productivity in the country (FOS, 1996). In the traditional Nigerian society, it is the women's responsibility to source fuel wood for cooking, but the task is becoming increasingly difficult, as the forests through which fuel wood was obtained are now receding due to desertification and population pressure on land. Women now have to work harder and further to get fuel wood. This takes both energy and time, and interferes with their agricultural and other activities. This study believes that the ease with which women can access fuel for cooking will determine the time, energy and other resources available for agricultural production. Consequently, the study has considered availability of cooking fuel as one of the factors affecting productivity worthy of study.

Therefore, given the mandate of the ADPs and the role of factors such as rural roads, rural water supply, agricultural credit and cooking fuel in productivity improvement, this study has undertaken an exploratory assessment of the availability of these factors to project (ADP) and non-project (non-ADP) cassava women farmers in Benue State, Nigeria. This is in order to determine the adequacy or otherwise of these resources for agricultural development in the area, and to make appropriate recommendations as per research findings.

\section{Materials And Methods}

2.1 Study area, sampling and data collection: The study area is Benue State, Nigeria. The State has a population of 4,219,244 (NPC, 2006), and a total land area of $34,095 \mathrm{~km}^{2}$ and lies between longitude $8^{0} \mathrm{E}$ and $10^{\circ} \mathrm{E}$, Latitude $6^{0} 3^{\circ} \mathrm{N}$ and $8{ }^{1 / 2} \mathrm{~N}$. Benue State consists of 23 Local Government Areas grouped into three Agricultural Zones A, B and C (BNARDA, 2001). Crops grown in the State include cassava, yams, sweet potatoes, citrus, mangos, oil palm. Other crops cultivated include rice, maize, millet, soyabeans, beniseed, groundnut, sorghum, ginger, sugarcane among others. Benue State also produces a great deal of livestock, forestry products and fish (Ater, 2003).

Multi stage sampling technique was adopted for the study. In stage one purposively selection of Benue State was for the study because it is the largest cassava producing state in Nigeria (Olasunkanmi, 2012). Stage two involved selection of two cassava producing local governments from each of the three agricultural zones in the state. Stage three was random selection of twenty-nine ADP twenty-nine non-ADP cassava women farmers respectively from the selected Local Governments in each zone giving a total of 87 ADP and 87 non-ADP respondents, and a grand total of 172 respondents for the study. Descriptive statistics such as means, percentages, pie charts and others were used to analyse data collected.

\subsection{Availability of Rural Roads}

\section{Results And Discussions}

Results show that only $8 \%$ of the ADP women farmers and $23 \%$ of the non-ADP women farmers have access to all season roads (very good and passable all year round), $64.4 \%$ the ADP and $47.7 \%$ of the non-ADP respondents had access to roads that were fairly good most of the year. Over a quatre (26.4\%) of the ADP and $21.8 \%$ of non-ADP respondents had access to roads that were impassable during the rainy season while $1.1 \%$ ADP and $11.5 \%$ of non-ADP had access to very poor roads that were not passable most of the year. Altogether, 72- $92 \%$ of all women farmers studied use roads which had one problem or the other during part of the year which make them impassable. This implies that the presence of the ADP notwithstanding, less than $30 \%$ of rural roads in the study area are accessible all year round. This can result to high transport costs with attendant inability to procure and transport inputs to areas of need, inability to evacuate and distribute produce to areas of high demand and need, with a resultant negative effect on respondents' income, poverty reduction and national 
development. This finding reaffirms UNDP (2008) that weak infrastructure is the bane of Nigeria's development efforts. Figure 1 gives the summary respondents' access to rural roads:

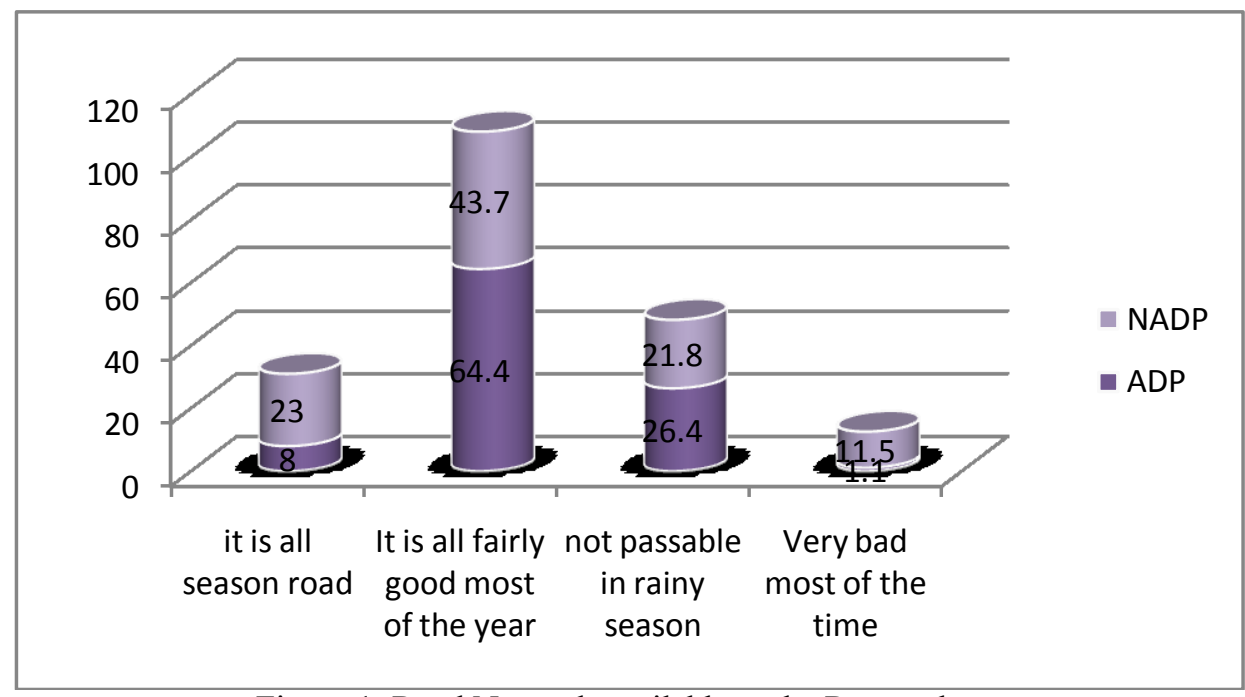

Figure 1: Road Network available to the Respondents

Source: Field data, 2010

This implies that there is a need for policies to beef up rural infrastructure such as roads to increase productivity and accelerate national development.

\subsection{Water Supply Sources of Respondents}

Water is one of the basic needs of life. Hence the ADP planners incorporated a water development component to ease the burden of sourcing water so that the women farmers can effectively carry out their production and other activities. The study assessed the sources of domestic water available to respondents. Results showed that majority of the ADP respondents (48.3\%) get their water from hand dug wells, $35 \%$ get their drinking water supply from streams (far or near) while $16.1 \%$ get theirs from borehole. Only about $6 \%$ of the non-ADP women farmers get their drinking water from borehole or public water supply, $65.5 \%$ get their water from hand dug wells while $28.7 \%$ obtain their drinking water from streams. Figure 2 shows available sources of water for respondents:

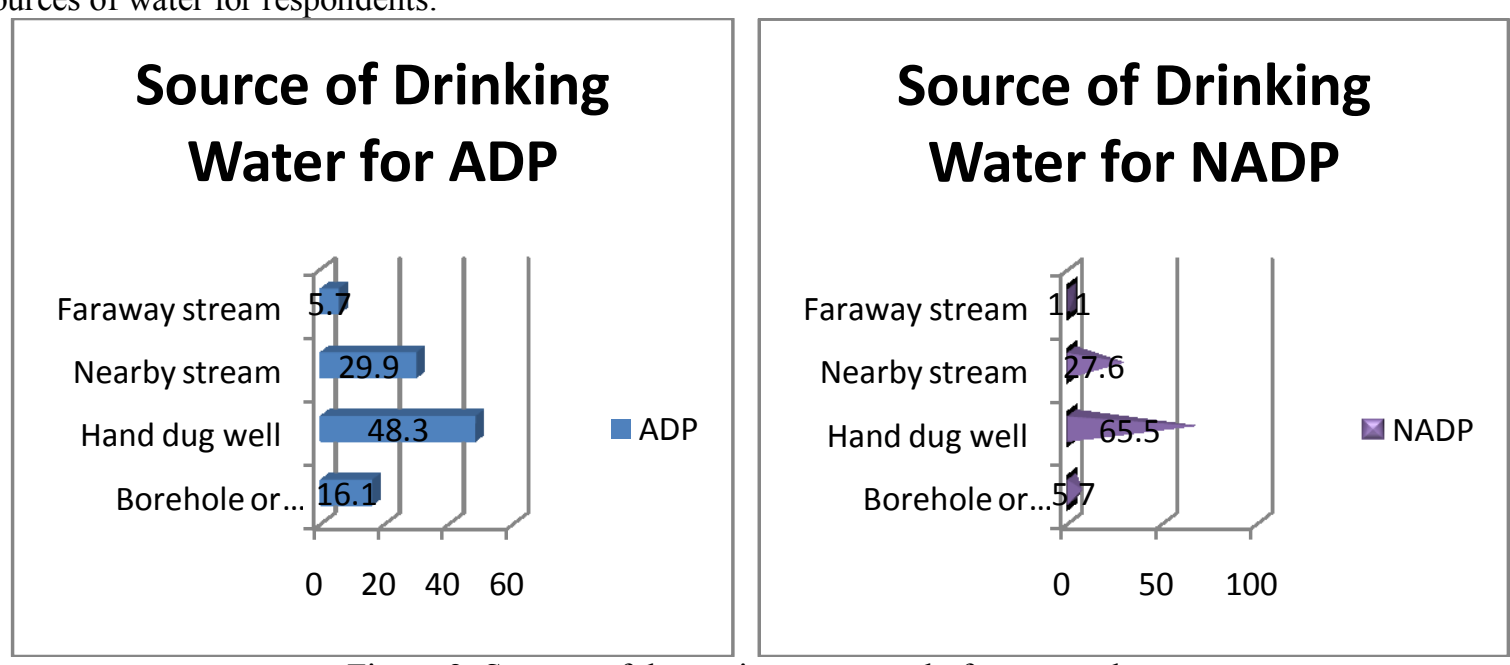

Source: Field data, 2010

This implies that negligible percentage of respondents get their water supply from sources close to them. Therefore, they would spend time and other resources looking for water. This is in line with Ogwumike (2000) that time wasted in searching for water by the women and children can be saved and devoted to other uses. Another implication of this finding is that since only $6-16.1 \%$ of all women farmers studied had access to clean water supply, getting water from sources other than hygienic sources (such as boreholes and pipe borne 
water) has implication for respondents' (their families and communities) health. An impure water supply can lead to ill health constraining productivity, income and welfare. This calls for policies to ensure provision of better and closer water supply for rural people in the study area and Nigeria at large.

\subsection{Respondents' Sources of Fund for Agricultural Production}

Data analysis showed that $77 \%$ of ADP and $80.5 \%$ of non-ADP respondents funded their farm operations from their personal savings, friends and relatives provided about $14 \%$ while money lenders provided $2.3 \%$ of the total funds for farm production. The Bank of Agriculture (formally Nigerian Agricultural Cooperative and Rural Development Bank), the main institution established to provide agricultural credit to farmers provided only about $7 \%$ of the funds while commercial banks collectively provided less than $1 \%$ of the funds study farmers used for agricultural production. Figure 4 shows respondents' sources of funds for farm production:

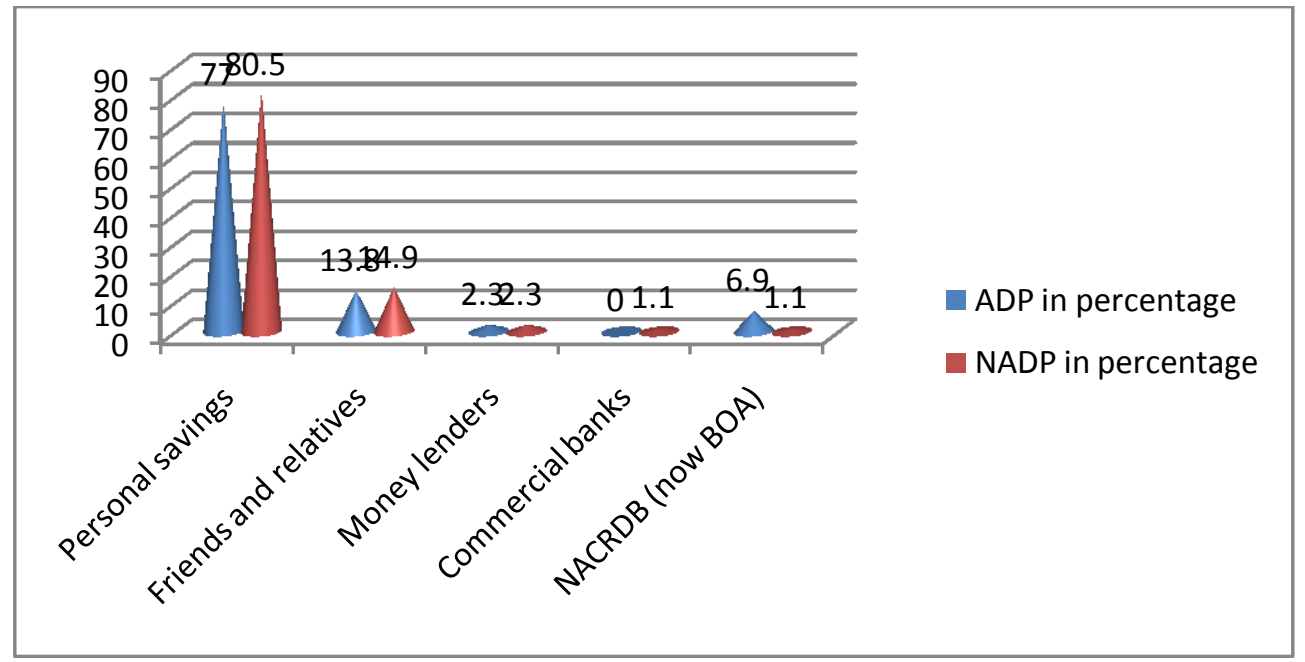

Figure 4: Respondents' Sources of Funds for Agricultural Production

Source: Field data, 2010

Altogether, $95.9 \%$ of the funds for cassava production by sampled women farmers came from informal sources (such as friends, personal savings). The implies that respondents do not have access to former sources of agricultural credit despite the existence of credit institutions with mandate to lend to agriculture. This findings agree with Eboh (2012) that the flow of credit to agriculture (in Nigeria) is meagre, and further noted that the Nigeria Agricultural Cooperative and Rural Development Bank (now Bank of Agriculture), the major institution responsible for funding agriculture in Nigeria, has extended only a negligible amount of credit to Nigerian farmers. This implies that there is need for policies to increase credit flow to agriculture, especially to women farmers such as those in Benue State for increased agricultural productivity and poverty reduction.

\subsection{Types of Cooking Fuel Available to Respondents in the Study Area}

Results showed that $86.3 \%$ of ADP and $94.3 \%$ of the non-ADP respondents had access to only fuel wood for cooking. The situation is worse among NADP women farmers where $94.3 \%$ use only firewood for cooking, and the rest (5.7\%) use kerosene and firewood. None of them could access either kerosene or gas alone. Altogether about $86-94 \%$ of study women farmers can only access fuel wood for cooking. This implies that they spend resources (their time and energy) which could have been devoted to meaningful agricultural production sourcing fuel wood for cooking. Another implication is this can deplete forest resources because the fuel wood is obtained by felling trees which are sometimes burnt to get charcoal, which is increasingly being preferred because it is neater. All over the study area fuel wood and charcoal are sold everywhere. This can degrade the environment and undermine agricultural productivity, sustainable agriculture, poverty reduction, and can also increase global warming. Figure 4 shows respondents' access to different types of cooking fuel : 


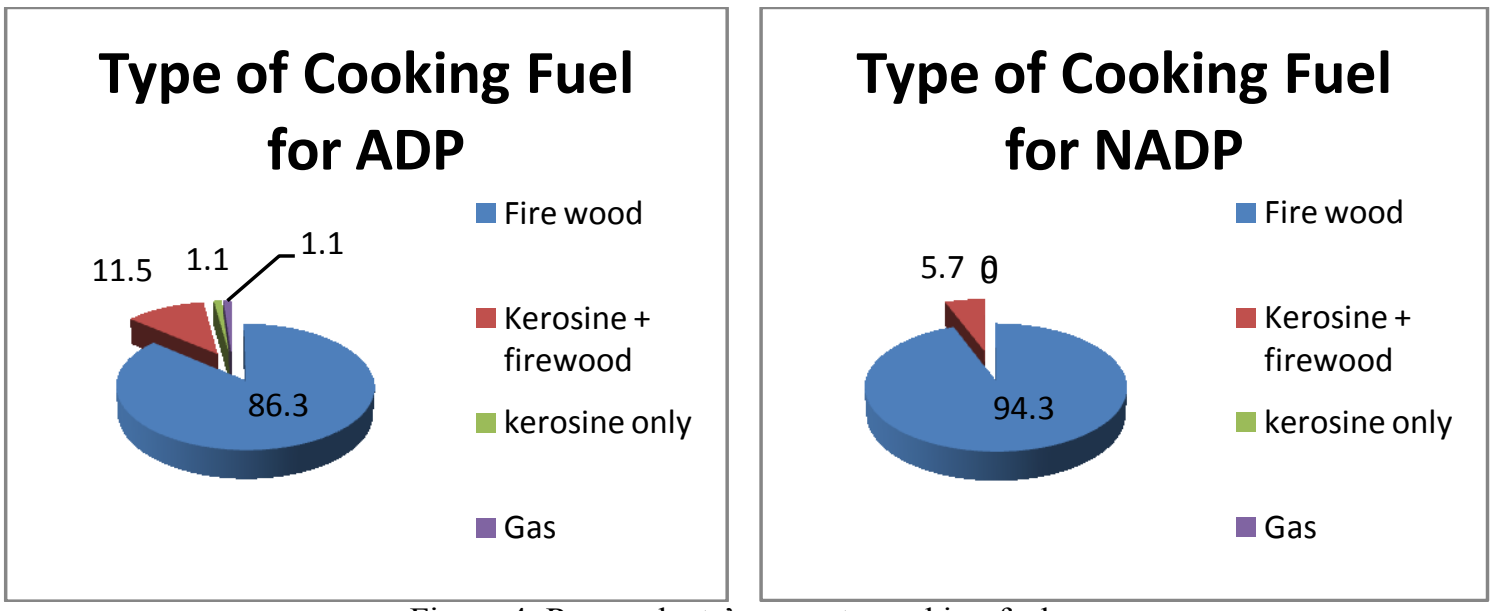

Source: Field data, 2010

This finding is in line with Van-Keulen (2007) that degradation of ecosystems is exacerbating problems of poverty and food insecurity in the developing world, particularly in the poorest countries (like Nigeria), where global climate change is taking place against a natural environment that is already stressed by resource degradation. The result also agree with Onyekuru and Eboh (2008) that acute deforestation driven by uncontrolled demand for wood, mostly for fuel wood, and also for export, has within a century reduced the country's (Nigeria's) forest cover to less than 38,620 square kilometers, less than five percent of its original size. The implied policy is to seek and develop environmentally friendly renewable energy cooking fuels for use in the study area and Nigeria as a whole.

\section{Conclusion And Recommendations}

This study assessed the availability of productivity improving resources such as rural roads, rural water supply, agricultural credit and cooking fuel among women farmers in Benue State, Nigeria. Data obtained through structured questionnaire administered to $87 \mathrm{ADP}$ and 87 non-ADP respondents randomly selected across Benue agricultural development zones, was analysed using descriptive statistics such as means, percentages, bar and pie charts among others. Results showed that over $72-90 \%$ of rural roads in the study area are in poor condition and impassable for certain periods of the year, thereby constraining free movement of inputs and output into and from the farms respectively, with negative effect on respondents' income, poverty reduction and national development. Results also showed that only $6-16.1 \%$ of all women farmers studied had access to clean water from public water supply, while the rest did not have with attendant consequences of ill health, reduced productivity, income and welfare. Results further showed that informal sources such as relatives and friends, money lenders and personal savings of respondents provided the bulk of the funds $(95.9 \%)$ for farm operations, while formal sources like commercial banks and the Bank of Agriculture provided the negligible balance. Furthermore, $86-94 \%$ of all study women farmers can only access fuel wood for cooking, and their consequent search for fuel wood can undermine agricultural productivity, sustainable agriculture, and poverty reduction.

Therefore, based on the findings of this research, the following recommendations are made:

The study showed that respondents have inadequate access rural roads and rural water supply in the study area. Therefore, the study recommends provision of these infrastructures to improve their productivity and improve welfare in the study area.

This study also showed the inability of respondents to access formal sources of funds (such as banks) for agricultural production, thereby relying on informal sources such as their personal savings, friends and relatives, and money lenders for funds which is little, and cannot help them in expanding their farm operations. Therefore, the study recommends that credit policies properly targeted at these farmers will tend to solve the problem and improve rural welfare.

The study further showed that a great majority of study women farmers can only access fuel wood for cooking, with attendant consequences on their health, productivity and welfare policies to develop and distribute environmentally friendly renewable energy cooking fuels such as ethanol gelfuel to solve the problem. Implied policy measure is to step up action on ethanol production from cassava or sugarcane for use as cooking fuel (gelfuel) to replace fuel wood or charcoal. A viable ethanol industry (from cassava / or sugarcane sources) in Nigeria will have added economic benefits of preventing environmental degradation (through provision of 
renewable energy fuels such as gel fuel for cooking, gasohol for vehicles), generation of additional revenue for government, job creation and increased income for producers among others.

\section{References}

[1]. Ahmed, R. and Hossain, M. (1990). Developmental impact of rural infrastructure in Bangladesh. IFPRI Research Report No.83. Washington D.C.: International Food Policy Research Institute.

[2]. Adegeye, A.J. and J.S. Dittoh (1985). Essntials of agricultural economics. Impact Publishers Nigeria Limited (new edition), Ibadan.

[3]. Arene and Omoregie, (1991). The place of Women in Agricultural Labour Force in Nigeria Beitrirop.I.andwirtsch.Vet.med.29(1991) H.3.277-282.

[4]. Ater, P.I. (2003). A comparative analysis of productivity response and poverty alleviation among beneficiaries of and nonbeneficiaries of World Bank assisted dry season fadama enterprises in Benue State.

[5]. Awotide, D.O., Fashina, O.M., Ologbon, O.A.C., and A Ggboola, P.O. (2008). Relationship between credit access and technical efficiency of maize farmers in Abeokuta North Local Government Area of Ogun State,Nigeria. Proceedings of the $10^{\text {th }}$ Annual National Conference of the Nigerian Association of Agricultural Economists held at University of Abuja on October, $7^{\text {th }}-10^{\text {th }}$.

[6]. BNARDA (2001). "The impact of Benue State Agricultural and Rural Development Authority on Agriculture and Rural Development in Benue State'. BNARDA Makurdi, Nigeria.

[7]. Eboh, E. C. (2011). Agricultural Economy of Nigeria: Paradoxes and Crossroads of Multimodal Nature. An Inaugural Lecture of the University of Nigeria delivered on January $27,2011$.

[8]. Fan, S. S., N. Thorat and N. Rao (2004). Investment, Subsidies and pro-poor growth in India. In Dorward et al (2004). Institutions \& Policies for pro-poor Agricultural Growth. Report on project 7989, Department for international Development. Social Science unit available at http://www.imperial/.ac.uk/agriculturalscience/research/section/aebm/project/poor-ag-download/finalrep.pef.

[9]. Federal Office of Statistics (1996). Annual Abstracts of Statistics Lagos: Federal Office of statistics.

[10]. Ijere, M. O. (1992). Leading Issues in Rural Development, Acena Publisher, Enugu.

[11]. Inoni, O.E. (2008). Impact of rural roads and marketing infrastructure on output and income of farming households in Ughelli South Local Government Area, Delta State. Proceedings of the $10^{\text {th }}$ Annual National Conference of the Nigerian Association of Agricultural Economists held at University of Abuja, $7^{\text {th }}-10^{\text {th }}$ October.

[12]. Jacoby, H.G. (2000). Access to markets and benefits of rural roads. The Economic Journal 110;713737

[13]. National Agricultural Extension \& Research Liaison Services (1997): Evaluation of the Effectiveness of Impact of the Training and Visit System in Nigeria. A Research Report submitted to Agric Project monitoring and Evaluation Unit (APMEU) of the Federal Department of Agric. 1 - 157.

[14]. National Population census (2006). Census figure Abuja, Nigeria.

[15]. Nwosu, C. S. (2005). Comparative Economics of Resource Use by ADP and Non-ADP Cassava Farmers in Orlu Agricultural Zone of Imo State, Nigeria. Proceedings of the $39^{\text {th }}$ Annual Conference of Agricultural Society of Nigeria, University of Benin, October $9^{\text {th }}-13^{\text {th }}$, pp $1-4$

[16]. Ogbimi, G. E. and Williams, S. (2001). Gender Sensitivity and Marginalised Groups. An Assessment of the Availability of productive Assets to Woman in Agricultural Development. International Colloquium Gender, Population and Development in Africa, Abidjan.

[17]. Ogwumike, M.(2000). Approaches to poverty alleviation. European Journal of Social Sciences Vol.15, No.1

[18]. Olasunkanmi, M.B., Afolabi, M., Daramola, F.(2012). Enterprise combinations in cassava based food crop farming systems Nigeria: Evidence from Ogun State. Greener Journal of Agric. Sciences Vol.2(1)pp013-20, January.

[19]. Onyekuru, N.A. and E.C. Eboh(2008). The Nigerian energy crisis and the need to avert the impending environmental disaster: A case study of household cooking energy sources in Enugu State, Nigeria. Proceedings of the $10^{\text {th }}$ Annual Conference of Nigeria Association of Agricultural Economics, $7-10^{\text {th }}$ October held at University of Abuja.

[20]. United Nations Development Programme (2008). Human Development Report. Oxford University Press, New York.

[21]. Van Keulen, H. (2007). Historical context of agricultural development. In: R.P. Roetter, H. Van Keulen, M. Kuiper, J. Verhagen and H.H. Van Laar (eds). Science for Agriculture and Rural Development in Low-income Countries, pp7-26.

[22]. World Bank (1994). Enhancing women's participation in economic development. A World Bank Policy Paper. The World Bank, Washington D.C.pp12-15 